\title{
Personnalité métaphysique et rites traditionnels mortuaires Sud Fore
}

Metaphysical personhood and traditional South Fore mortuary rites

Jerome T. Whitfield, Wandagi H. Pako and Michael P. Alpers

\section{(2) OpenEdition \\ 12 Journals}

\section{Electronic version}

URL: http://journals.openedition.org/jso/7384

DOI: $10.4000 /$ jso.7384

ISSN: $1760-7256$

\section{Publisher}

Société des océanistes

\section{Printed version}

Date of publication: 15 December 2015

Number of pages: $303-321$

ISBN: 978-2-85430-126-7

ISSN: 0300-953x

\section{Electronic reference}

Jerome T. Whitfield, Wandagi H. Pako and Michael P. Alpers, «Personnalité métaphysique et rites traditionnels mortuaires Sud Fore », Journal de la Société des Océanistes [Online], 141 | juillet-décembre 2015, Online since 15 December 2018, connection on 19 April 2019. URL : http:// journals.openedition.org/jso/7384; DOI : 10.4000/jso.7384 


\title{
Metaphysical personhood and traditional South Fore mortuary rites
}

by

\author{
Jerome T. WHITFIELD*, Wandagi H. PAKO ${ }^{* *}$ and Michael P. ALPERS ${ }^{* *}$
}

\begin{abstract}
Ethnographic studies on Melanesian concepts of the human body and religion have expanded our understandings of the concept of personhood. Melanesian ethnographers have used a number of descriptive words to describe the metaphysical components of the person, including: soul, spirit, life force, ghost, and vital and spiritual essence. By investigating the traditional mortuary rites of the South Fore people in Papua New Guinea, which included the practice of endocannibalism, investigators were able to distinguish the 5 souls of the composite metaphysical person and their relationship to the humors of the body. An understanding of the South Fore cosmology and its relationship to its human inhabitants was required to understand these deeply embedded concepts. The South Fore person was found to be composed of 5 souls and bodily humors which together formed a composite individual, yet partible through division. We elucidated the concepts of the 5 souls of the Fore person, which revealed a strong correlation between the landscape with its overlying cosmology and the cultural bodily humors, and demonstrated their relationship to the power of the land.
\end{abstract}

KEYwords: personhood, soul, mortuary rites, South Fore, cannibalism

This paper examines concepts of metaphysical personhood of the South Fore people in Papua New Guinea (PNG) by examining the 5 souls of the person that are released from the body at death (see map 1). This approach follows the lead of Stephen

\section{RÉSUMÉ}

Les études ethnographiques sur les concepts mélanésiens $d u$ corps humain et la religion ont élargi notre compréhension de la notion de personnalité. Les ethnographes mélanésiens ont utilisé un certain nombre de mots descriptifs pour décrire les composants métaphysiques de la personne, y compris l'âme, l'esprit, la force de vie, le fantôme et l'essence vitale et spirituelle. En enquêtant sur les rites funéraires traditionnels $d u$ peuple du Sud Fore (PNG), avec une pratique de l'endocannibalisme, les enquêteurs ont été en mesure de distinguer les cinq âmes de la personne métaphysique composite et leur relation avec les humeurs du corps. Une bonne compréhension de la cosmologie du Sud Fore et sa relation avec ses habitants humains ont été nécessaires pour comprendre ces concepts profondément ancrés. La personne du Sud Fore est donc composée de cinq âmes et humeurs corporelles qui, ensemble, forment un individu composite, encore divisible. Ici est donc élucidé le concept des cinq âmes de la personne Fore, qui révèle une forte corrélation entre le paysage avec sa cosmologie sus-jacente et les humeurs corporelles culturelles, et la preuve de leur relation à la puissance de la terre.

MoTS-CLÉs : personnalité, âme, rites mortuaires, Sud Fore, cannibalisme

* MRC Prion Unit and Department of Neurodegenerative Diseases, Institute of Neurology, University College London, National Hospital for Neurology and Neurosurgery, and Papua New Guinea Institute of Medical Research, Goroka, j.whitfield@prion.ucl.ac.uk

${ }^{* *}$ Papua New Guinea Institute of Medical Research, Goroka

*** Centre for International Health, Curtin University, Perth, Australia 


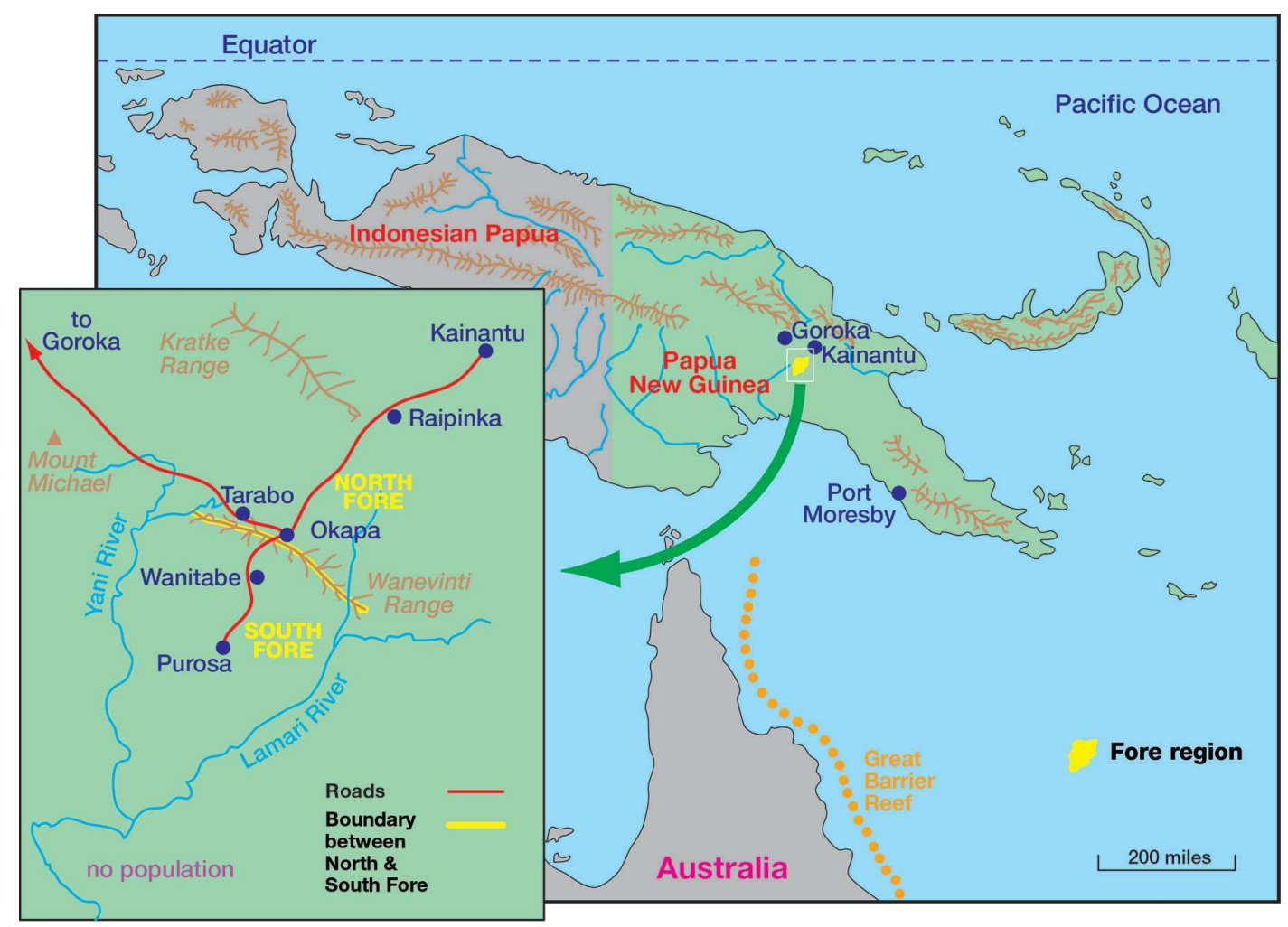

Map 1. - Papua New Guinea. The insert shows the location of the Fore linguistic group who inhabit the Okapa District of the eastern highlands of PNG, and have been divided administratively and geographically into the North and South Fore. There are three dialects of the Fore language, ibusakamana spoken in the North Fore, and atikamana and pamusakamana spoken in the South Fore

souls in a rich ethnographic description of South Fore mortuary rites to avoid imposing exogenous constructs on indigenous concepts, and avoided the overuse of analytical language, so the unity of South Fore cultural concepts could be revealed.

This approach elucidated a relationship between the humors of the body (Stewart and Strathern, 2001) and their counterpart souls (Whitfield et al., 2008). The extension of the deceased person in mediated and unmediated exchanges (Strathern, 1990) during mortuary rituals contained power through the 5 souls of the person. This power originated in the overlaying cosmology written into the landscape (Tilley, 1994), which was part of the overall cosmos (de Coppet and Itéanu, 1995) and capable of penetrating a person's personal space through the power of truth (Weiner, 1983). In this case cosmos is defined as:

" [...] cultural ideas in general set into overarching notions of a world beyond each individual person to which the body belongs. » (Stewart and Strathern, 2001: VIII)

\section{Metaphysical personhood in Papua New Guinea}

Metaphysical components of personhood have been described by anthropologists in relation to dreams and death. In this exposition we examined ethnographic descriptions of Melanesian concepts of embodied souls and spirits to further our understanding of personhood. Rivers (1920) wrote about soul-substance in Melanesia, and described the belief in two souls found amongst the inhabitants of the Tami Islands. Malinowski (2008) described the spirits of the dead in the Trobriand Islands called baloma and kosi. Rosalind Moss (1925) brought together data from a variety of sources about mortuary customs in Polynesia, Melanesia and Indonesia. She used the terms ghost, soul and soul-substance in her descriptions. In New Ireland, life-force was transferred from the corpse to a Malangan sculpture and finally released during the rotting of the sculpture (Kuchler, 1988). Panoff (1968) provided a deep description of the notion of the double self among the Maenge, who inhabit the south coast of New Britain. Panoff was cautious in his definition of these entities, avoiding the use of "soul" which stresses spiritual faculties and "substance" that would undermine the dual nature of the Maenge.

Schieffelin (1976) described the Kaluli concept of mama, which meant shadow or reflection of a living person, which inhabited a world on the slopes of Mount Bosavi. Here the mama of a man appeared as a pig, and of a woman as a cassowary. The souls of the deceased followed rivers west from Mt Bosavi, and these rivers appeared as broad 


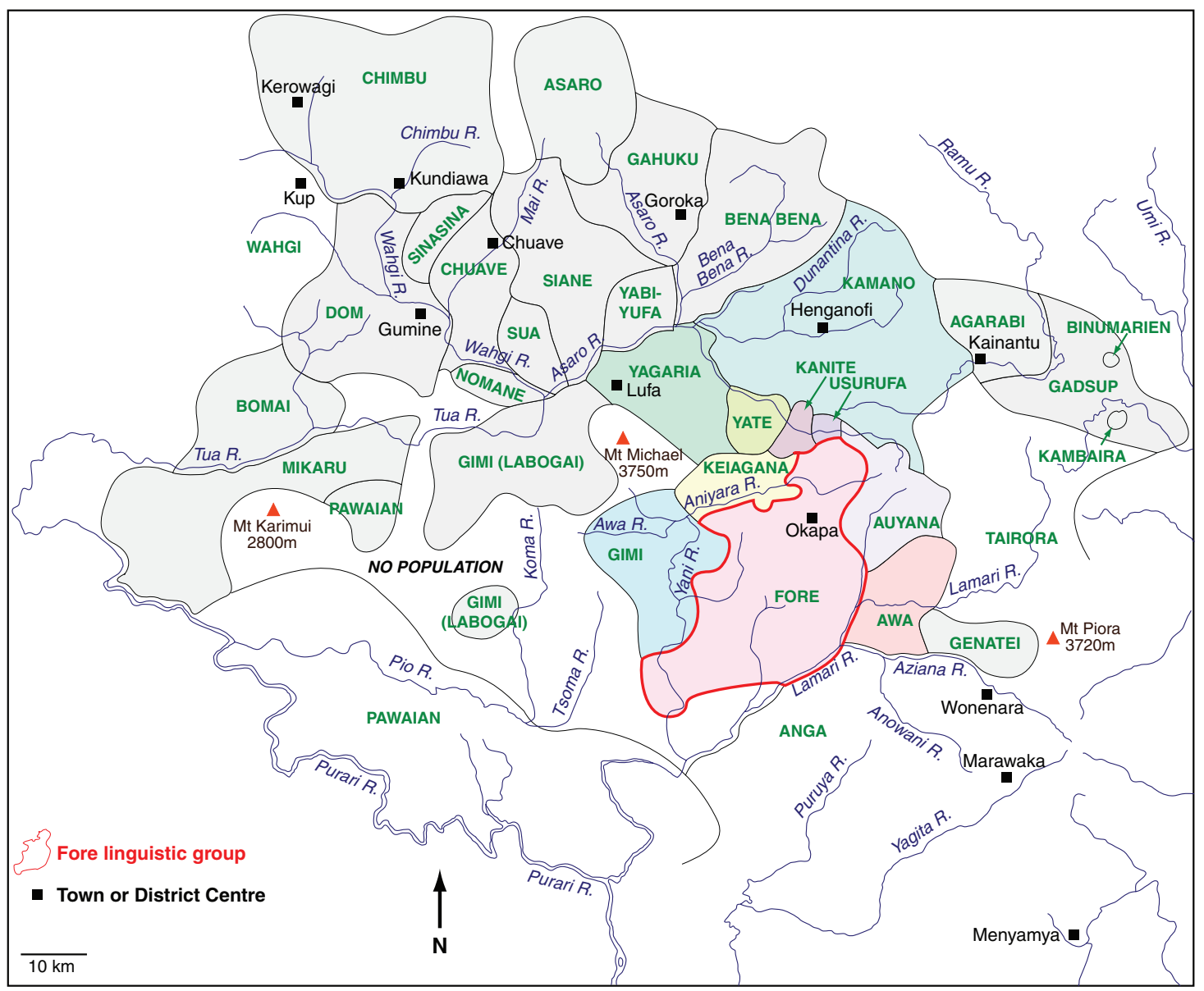

Map 2. - Map showing the linguistic groups of the eastern highlands and bordering central highlands. The Fore linguistic group is highlighted with a red border

roads to the souls. Eventually the roads converged in an all-consuming fire called imol, where the dead were consumed by flames and reborn as ane kalu (Schieffelin, 1976).

In the western highlands region of PNG descriptions of the metaphysical person were found for the Huli, Kyaka Enga and the Mae Enga. Robert Glasse (1965) wrote about the immaterial essence of human personality of the Huli, which survived death in the form of a ghost which could affect the living. The Mae Enga believed that a person's spirit was in some way implanted into a child from the totality of the ancestral spirit pool. When a person died the spirit became a ghost and remained with the corpse till burial, after which it wandered through the clan's land (Meggitt, 1965: 110). The Kyaka Enga believed that a person's soul, called imwambu, became a ghost after death. Shadows or reflections of the deceased were also called imwambu (Bulmer, 1965). Stewart and Strathern (2001: 131-136) summarized descriptions of noman amongst the Melpa, nomane amongst the Maring, and the Kuman term nomana and its variants: noman, nomane and nomanao. The Kuman words were translated as opinion, feeling, belief, intellect, soul, insight, heart, thought and custom. Their discussion highlighted the difficulty of translating metaphysical meanings, and how different words are used by different linguistic and dialect groups which may or may not share a common meaning. In the eastern highlands of PNG descriptions of the souls and spirit components of the person were found for the Simbari, Siane, Daribi, Asaro, Gadsup, Tairora, Gimi, Yagaria and the Fore (see map 2). Herdt (1977) described the mediating role of shamans and their spirit familiars between ghosts of the dead and the souls of the living, and how male initiates acquired spirit familiars. Salisbury (1965) wrote about the Siane, who believed that men, pigs and certain other animals had a body and a spiritual aspect which he called 'spirit' and described as a 'non-discrete spiritual essence'. The Siane called the spirit oinya, which turned into korova at death and during a later ceremony joined an undifferentiated pool of korova, from which korova subsequently entered another body to become oinya (Salisbury, 1965: 55). According to the Daribi, a person was not born with a soul (noma); instead it developed within them as they grew. After death the noma became an izibidi (ghost) (Wagner, 1967). When 
a person died in the Asaro his vital essence took the form of a ghost called foroso, which remained in the vicinity of the living (Newman, 1965). Du Toit (1975) stated that amongst the Gadsup the soul had a visual dimension called timami, and a manes dimension called aumi. The timami departed from the body at death, but the aumi remained near the corpse and after burial it departed to become an ancestor. Watson (1983) mentioned an afterworld in the Saruwaged Range to the north of the Tairora. The land of the dead was called bánamáqa, and ghosts (bana) could return and frighten humans or assist them.

Anthropological studies were conducted amongst the northwesternmost Gimi by Glick (1963) and Gillison (1993). Glick translated the term aona as vital force, shadow or soul. He regarded the use of the word soul as misleading as it suggested immortality, a concept that the Gimi rejected. Aona also meant familiar spirit, and a human might take on the aona of an animal, which then became his familiar spirit. Glick used the single word 'power' to define aona. Gillison described aona as:

"auna is the life force that motivates people, pigs and other sentient beings including the kore or ghost. It arises in the head and moves in the blood to the heart, producing pulse and heartbeat. auna fills the lungs, liver, and other organs with 'wind' and is exuded in breath, voice, sweat, tears, intestinal gas [...] »(Gillison, 1993: 108)

The Hua, a dialect group of the Yagaria, had the concept of aune, the positive aspect of $n u$, described as 'vital essence' (Meigs, 1995: 18). Meigs described aune as a possible cognate of the Siane notion of oinya identified by Salisbury (Meigs, 1995: 125).

In Graham Scott's Fore dictionary naumáwé refers to spirit, breath or soul. The departed soul or spirit of the deceased is called amanane. Kweraye means evil spirit, devil, demon or Satan in Fore (Scott, 1980: 216). Eségenáyé is the word for strength, might, power, toughness, courage and authority (Scott, 1980: 34).

The indigenous concepts have been described in a variety of ways, including soul, spirit, life force, ghost, vital essence and spiritual essence. The data highlight the importance of ethnographic investigation to elicit understandings of indigenous concepts within the unity of their context, rather than the meaning of isolated words. Strathern (1990) has emphasized the importance of the correct translation of indigenous concepts:

\footnotetext{
"The task is not to imagine one can replace exogenous concepts by indigenous counterparts; rather the task is to convey the complexity of the indigenous constructs in reference to the particular context in which they are produced. » (Strathern, 1990: 8)
}

At the same time she cautions against the dangers of analytical language:
"Analytical language appears to create itselfas increasingly more complex and increasingly removed from the 'realities' of the worlds it attempts to delineate, and not least from the languages in which people themselves describe them. " (Strathern, 1990: 6)

Finally, Strathern acknowledges that it is important to recognize that Melanesians have their own whole unities that can be obscured by our own analysis (Strathern, 1990: 11-12).

These three points raised by Strathern are relevant to the choice of words used to describe Melanesian metaphysical aspects of the person that depart from the body at death. The term soul is avoided by some anthropologists (Gillison, 1993; Glick, 1963; Panoff, 1968), and used by others (Herdt, 1977; Herdt and Stephen, 1989; Schieffelin, 1976). Herdt pointed out that in the past it had been assumed that the word soul needed little translation, and was analogous to the Christian theological definition, a misconception Herdt and Stephen (1989) have removed. Previously, we have used the term soul (Whitfield et al., 2008), and continue to do so in this paper. We define it as the part or parts of the person that depart from the body at death. The Fore describe 5 departing souls, which differ widely in their detailed attributes. Other terminologies are less satisfactory. The term 'spiritual essence' suggests an undivided entity (Panoff, 1968), and the term 'spirit' is often associated with ghosts (Parrinder, 1989). To understand the concepts of the 5 souls of the South Fore we discussed the matter in depth with many Fore people and to place these concepts in their universal context we have turned to ethnographic descriptions and not relied on analytical language, whilst acknowledging the difficulties of matching exogenous concepts with indigenous ones.

Although there are ethnographies about the South Fore's neighbours in the eastern highlands, as mentioned above, few contain detailed descriptions of cosmologies and mortuary rites necessary for the investigation of the partible person apparent in death (Bonnemère, 2014: 740). Meigs (1995) understood Hua religion in terms of the regulation of an individual's vital substance, but does not mention mortuary rites. Her understanding of mortuary anthropophagy was based on food rules (Meigs, 1995: 40). Gillison (1993) interpreted Gimi beliefs in terms of myth, allowing her theoretical analysis to ignore statements made by her informants (Lipset, 1994: 164). More recently, preliminary investigations throughout the eastern highlands do suggest that many of the linguistic groups of the Eastern Family and the East-Central Family of the East New Guinea Highlands Stock might share similar beliefs in the five souls of the person (Whitfield, 2011). 


\section{Melanesian personhood}

The subject of Melanesian personhood was invigorated by Leenhardt's 'Do Kamo', which became available in English in 1979, and contributed to the early literature. Leenhardt often recounted his proposal to Boesoou Erijisi, his oldest convert:

«In short, what we've brought into your thinking is the notion of spirit " [or mind: spirit]

To which came the correction:

«Spirit? Bah! We've always known about the spirit. What you brought was the body. " (Clifford, 1992: 172)

Leenhardt struggled with the Descartian mind-body dualism, and saw the centre of a Melanesian's relationships as empty: there was no separation of the outside from the inside defined by the body (Clifford, 1992: 185). However, Strathern disparaged the idea of an empty centre where western imagination puts the self (Strathern, 1990: 269). Strathern saw the person as objectified through the relationships that constitute him or her, which she referred to as the partible person. During mediated exchange the objects of the transaction, such as shells or pigs, were conceptualized as part of the person, and seen as extracted from one person and absorbed into another, carrying influence in the part. In unmediated exchange people had a direct effect on the lives and bodies of their relatives through substances such as semen or blood (Strathern, 1990: 178). The internal body was composed of the relationship of substances, and the external was concerned with relationships with people, thus making the body appear as the result of human actions (Strathern, 1990: 208). However, the notion of the partible person is a western conceptual approach to investigations of relationships and exchange, and not one that the South Fore would recognize in their daily understanding of the embodied person. It is only in death that the South Fore person becomes the partible person that is so amenable to the analysis of personhood (Bonnemère, 2014: 740).

The discussions on Melanesian personhood have been well summarized (Biersack, 1990; Bonnemère, 2014; Lindenbaum, 2008; Wardlow, 2006). Not everyone agreed with Marilyn Strathern, and some viewed her approach as static and believed that an actor-orientated and ethnohistorical approach would expose more complex shifting modes of personhood (Stewart and Strathern, 2000a). Melanesians also valued individual achievements and selfassertion (Stewart and Strathern, 2000b). It is now generally accepted that both relationality and individuality exist together, but with varying emphasis in different cultures (LiPuma, 1998; Lindenbaum, 2008).

More recently the debate about personhood has moved to new forms of individualism, as modernity has transformed traditional understandings (LiPuma, 1998: 53). Robbins (2004) has written about the transformation of the Urapmin by local charismatic Christians, which led them to abandon their traditional religion, sacred houses and ancestral bones.

Another approach to investigations about Melanesian personhood was advocated by Stephen (1989), who convincingly argued her exposition that concepts of personhood and self need to be understood through indigenous concepts of embodied souls. The concepts of souls were linked to sacred ancestral powers from which the living gained access to knowledge and power. Consciousness was found in these souls, which were part of the person's body yet distinct from it.

Stewart and Strathern (2001) wrote about humors of the body (blood, fat and water) and substances, such as bone and spittle. In Papua New Guinea bodily fluids were seen to modify behaviour, whilst bodily thermal states were seen to modify health. Anna Meigs (1995) wrote about the bodily states of the Hua in the eastern highlands of Papua New Guinea, and how they maintained a bodily balance between hard and soft substances. In trying to understand how the souls of the deceased person extend out from humors or objects during exchange, Herdt suggested that:

"The self invests in these particular concepts and narratives. The I/me extends out beyond the boundaries of one's skin through imagination into a world of symbolic objects indexed in the discourse of others. " (Herdt, 1989: 27)

Such an approach removes the false analytical dichotomies of natural-supernatural and religiousprofane. As Geertz pointed out:

" the world as lived and the world as imagined [...] turn out to be the same world. » (Geertz, 1973: 112)

These concepts in turn needed to be understood within the wider understanding of the cosmos, its power and its relationship to the human inhabitants. Cultural ideas were set out in an overarching view of the world which were beyond the individual, yet to which the body belonged. This world was not static but undergoing constant flow and change as experienced by the environment and its inhabitants, and the bodies and souls of the inhabitants were part of this process. The person was part of the cosmos, yet maintained an individual aspect (Stewart and Strathern, 2001). To understand the process it was necessary to 
understand the relationship between personhood and cosmos through the souls and humors that constituted the composite person at birth, during initiation and throughout adulthood, and those that were released at the death of the person.

To investigate further the concepts of personhood we turned to Morphy (1990), who divided Yolngu myths into two categories, those of creation and those of inheritance. Myths of creation were about the creation of the landscape, and the ancestral beings, and those of inheritance were about the humans who inhabited the landscape and their rights to the land. The myths of creation help us to understand personhood. The close relationship between personhood, the landscape and its overlying cosmology has been well documented for indigenous Australians and others (Tilley, 1994).

Tilley (1994) pointed out that places are both empirical and the result of the inhabitants' social practices. The physical and sensory resources of the landscape were drawn on for the creation of cosmologies, social identity, social relations and social reproduction. As the landscape was drawn on in daily activities its power permeated its inhabitants and their social and cultural activities (Tilley, 1994). We define power as the capacity to influence abilities, emotions, actions and outcomes.

The power found in the landscape came from the overlying cosmology, which explained the creation of the world and its inhabitants. The durability and rarity of mythological locales in the landscape were the foundation of the truth of these events which gave power to these myths and their interpretations. Power itself was evident in the truth of the past and could be traced through the clan ancestors to the mythical creator. The power of the cosmology and landscape were evident in the power of speech to destroy and create, and nothing was more powerful than the speech of the ancestors and the creator. The power of truth entered an individual's personal space and this was the basis of its power. As Weiner (1983) pointed out, truth could disrupt and destroy, as well as bring order and create.

In the mediated and unmediated exchange of South Fore mortuary rituals we followed the atomization of the double self and followed the transference of the souls and their corresponding humors. We investigated South Fore understandings of personhood in relation to the cosmos, and traced the power of these exchanges back to the cosmology in the landscape.

Although not the focus of this paper, the ethnographic data shows the vital role played by women in rituals in a male-dominated society (Bonnemère, 2004). In the South Fore women were often referred to as the wombs of the men's cult houses, and the importance of their female reproductive powers recognized in the agnateaffine relationship. The most powerful warrior skills were endowed by the souls of deceased women to male initiates or warriors.

The data presented, which included field notes and transcriptions, were collected between 1996 and 2010, and based on interviews with 65 men and 11 women. The gender imbalance is very apparent in the South Fore, with many villages having no elderly women. The gender imbalance of the interviewees was the result of the epidemic of kuru, a neurological disease found amongst the Fore and some of their neighbours, which devasted the older generation of women (Alpers, 2007). Although we present a predominantly male viewpoint based on the larger number of male interviews there was congruence with the narratives collected from the elderly women.

Although adult males did not participate in eating the dead, the men who were interviewed had participated in or witnessed mortuary feasts as children, and some ceased to participate at the age of about 14. At the height of the kuru epidemic 2\% per year of the population of villages in the epicenter of the disease were dying of kuru (Mead et al., 2009), and those interviewed are likely to have participated in or witnessed at least 10 mortuary feasts. The team conducted interviews in 20 different villages with members of 24 different clans.

The anthropologist (JTw) lived and worked in Papua New Guinea for 7 years and continued to conduct fieldwork on a regular basis for a further 7 years. The anthropologist was also a qualified nurse with a background in emergency and tropical medicine and these skills were used to benefit the communities. The project also sourced funding for community development projects and oversaw the establishment of schools, water supplies, a village birth attendant program and malaria control. The project employed 14 local full-time staff and casuals when required. Long periods were spent visiting communities within the South Fore and other kuruaffected communities, as well as many others throughout the eastern highlands. There was a close relationship during this time between the anthropologist and staff whose extensive kinship ties enabled the team to work in many different communities. MPa has worked within and as part of Fore communities for 50 years in a relationship built of mutual respect and trust (Alpers, 2014). The importance of time in the field and relationships of mutual indebtedness and trust have already been described by Mallett (2003: 273) in relationship to reciprocal entrustment with customary knowledge.

Local staff, especially David Ikabala and Sena Anua, conducted initial interviews with elderly people who had participated in or witnessed anthropophagic practices, based on their kinship ties. This allowed the team to gauge the participant's willingness to divulge traditionally 
secret information and the response of the local communities. Once the team concluded that the participants were delighted to talk about their traditional way of life and experiences, in-depth interviews were conducted by the anthropologist and other team members using group interviews. During these interviews WHP contributed extensively with the translation of concepts, and the team used Fore, Tok Pisin and English languages to develop understandings of the mortuary rituals and their concepts.

Interpretations of South Fore mortuary practices by colonial patrol officers, kuru investigators and anthropologists have not been uniform, and their historicity has been accessed diachronically in a separate paper, which also takes into account the colonial encounter and the traumatic kuru epidemic (Whitfield, 2015).

\section{South Fore cosmology}

The people of the Fore linguistic group inhabit the Okapa District of the eastern highlands of Papua New Guinea, and have been divided geographically and administratively into the North and South Fore. There are two dialects spoken in the South Fore, the atikamana spoken by the atigina and the pamusakamana spoken by the pamusagina. The names used here are those of the pamusakamana dialect, and may be slightly different in atikamana.

To understand South Fore concepts of the metaphysical person it is necessary to start by investigating South Fore cosmology. The mythology explains the connection between the land (bagina), the creation of the sacred ancestors (amani) whose descendants make up the clans found in the Okapa region today, and the eschatological beliefs behind their traditional mortuary rites.

The South Fore have their own traditional explanations for the origin of the universe, as they experienced it prior to the colonial encounter. Their myths are located in time through genealogies which connect the living to the founding ancestors of the clans and finally back to the bagina.

The rivers are the blood, the stones the bones, the ground the skin and the plants the hair of the bagina. The bagina is the land, and it created the amani, the sacred ancestors of each clan, from whom men are descended, and once the amani were created the bagina changed back to its original form - the land. Everything came from the bagina and was eaten by the bagina when it died. According to the South Fore, their creation myth and that of other linguistic groups was called kalukalu. In the myth an old man, the bagina, cooked a bone with wild green vegetables in a bamboo tube and created the amani at a place called Andai (Whitfield, 2011: 152-157).

Another myth told the story of a male and female amani who travelled from Andai (the place of creation in Ivaki in the previous myth) up the Lamari River Valley to Manyavindi. The amani settled in Manyavindi (which is near the village of Okasa) and the population grew until eventually the offspring of the founding amani spread out into their own lands, and their descendants make up the human clans of the region today. The amani were the guardians of the bagina, and the portal through which humans interacted with the hidden powers of the bagina. They were similar to humans, but physically more powerful and more knowledgeable about the powers of the bagina. The term amani was also used for the sacred grounds of the amani, which consisted of a cave that led to kwelanamandi (the land of the ancestors), a lake, a mountain, a pine grove and palm trees (Whitfield, 2011: 158-175).

All the founding clans of the South Fore had a tunnel from their amani ground that led into kwelanamandi, through which the souls of their dead clansmen and clanswomen travelled after death. It was very similar to the land of the living, but there were no wars, sorcerers or famines, and the dead lived a much pleasanter life than the living. It was like a dream world where time did not exist, and when people dreamed of the dead they visited kwelanamandi (Whitfield, 2011: 175-176).

\section{The five souls of the South Fore}

The South Fore metaphysical person consisted of 5 souls connected to corporeal humors (Table 1). There was no single term to describe the souls in the Fore language; however, today the South Fore use the word soul to describe the 5 traditional souls. The Fore members of some Christian denominations, such as the Seventh Day Adventists and Salvation Army, retain their belief in the 5 traditional souls.

The Fore believed that a person's auma, ama, bones and patrilineal blood are formed from the father's sperm. Furthermore, the South Fore emphasize patrilineal blood as the substance that defines patrilineal descent from a clan's amani. The matrilineal blood and flesh are a source of pollution for initiates and men and become the dangerous ghost called kwela after death. The Fore do not deny human biology, but have their own parallel social construction of the person which also explains human biology.

A Fore adult man or woman had 5 souls contained within the body of the living that dispersed after death. A person was born with auma, ama and kwela, and these three souls eventually reunited after death to become an ancestor in kwelanamandi. The 


\begin{tabular}{|c|c|c|c|}
\hline \multicolumn{2}{|c|}{$\begin{array}{l}\text { The partible person of the South Fore person } \\
\text { apparent at death }\end{array}$} & Intermediate period & Final ceremony \\
\hline \multicolumn{2}{|c|}{$\begin{array}{l}\text { The five souls of the South Fore Person and } \\
\text { their corresponding bodily humors }\end{array}$} & \multirow{2}{*}{$\begin{array}{l}\text { Period between death and the } \\
\text { final ceremony. }\end{array}$} & \multirow{2}{*}{$\begin{array}{l}\text { This marked } \\
\text { the end of the } \\
\text { mortuary rituals } \\
\text { and the departure } \\
\text { of the deceased's } \\
\text { souls to the land o } \\
\text { the ancestors. }\end{array}$} \\
\hline Souls & Humors & & \\
\hline $\begin{array}{l}\text { auma } \\
\text { The I/me, consisting } \\
\text { of a person's good and } \\
\text { distinguishing qualities }\end{array}$ & $\begin{array}{l}\text { Located in the } \\
\text { centre of the body }\end{array}$ & $\begin{array}{l}\text { The auma travelled to the } \\
\text { land of the ancestors and } \\
\text { awaited the ama and kwela. }\end{array}$ & \multirow{3}{*}{$\begin{array}{l}\text { These three souls } \\
\text { were reunited } \\
\text { in the land of } \\
\text { the dead, where } \\
\text { the deceased } \\
\text { was reborn as an } \\
\text { ancestor. }\end{array}$} \\
\hline $\begin{array}{l}\text { ama } \\
\text { A simulacrum of the } \\
\text { auma with magical } \\
\text { powers to help the } \\
\text { mourning family } \\
\text { members }\end{array}$ & $\begin{array}{l}\text { Located in the bones } \\
\text { (patrilineal } \\
\text { substance) }\end{array}$ & $\begin{array}{l}\text { The patrilineal bones were } \\
\text { separated from the matrilineal } \\
\text { flesh and blood. The ama } \\
\text { assisted the family during the } \\
\text { mortuary rites. }\end{array}$ & \\
\hline $\begin{array}{l}\text { kwela } \\
\text { The dangerous ghost } \\
\text { of the deceased. }\end{array}$ & $\begin{array}{c}\text { Formed from the } \\
\text { deceased's flesh and } \\
\text { blood, consisting } \\
\text { mainly of matrilineal } \\
\text { substance, but also } \\
\text { some patrilineal } \\
\text { substance }\end{array}$ & $\begin{array}{l}\text { The dangerous kwela } \\
\text { consisted of mainly matrilineal } \\
\text { substance at the start of the } \\
\text { intermediate period, but by } \\
\text { the end it was transformed } \\
\text { into a benign soul consisting of } \\
\text { patrilineal substance. }\end{array}$ & \\
\hline $\begin{array}{l}\text { aona } \\
\text { A person's abilities } \\
\text { which are also apparent } \\
\text { in their spirit familiar. }\end{array}$ & $\begin{array}{l}\text { Found throughout } \\
\text { the body }\end{array}$ & \multirow[b]{2}{*}{$\begin{array}{c}\text { The aona remained with the } \\
\text { ama and the yesegi with the } \\
\text { kwela. }\end{array}$} & \multirow{2}{*}{$\begin{array}{l}\text { These abilities } \\
\text { were inherited by } \\
\text { the deceased's eldest } \\
\text { child of the same } \\
\text { sex. }\end{array}$} \\
\hline $\begin{array}{l}\text { yesegi } \\
\text { The power/aggression } \\
\text { of a person, also } \\
\text { apparent in the } \\
\text { character of their spirit } \\
\text { familiar }\end{array}$ & $\begin{array}{l}\text { Located on a } \\
\text { person's skin }\end{array}$ & & \\
\hline
\end{tabular}

TABLE 1. - The five souls of the South Fore person, their bodily humors and their manifestation during mortuary rites

aona and yesegi were transmitted during initiation and mortuary rituals. The following are descriptions of the five souls. However, to fully understand the 5 souls of the South Fore and to apprehend these allusive indigenous concepts it is necessary to analyse them in the context of traditional mortuary rites.

\section{Auma}

The following are descriptions of what auma means to the Fore.

"It's your love. »

"It's the inspired thought from your heart. "

"A character who smiles at you from afar when he sees you. "
"Whatever good we have comes from our auma." " Free-willed speeches that we make."

"Mutual friendship is inspired by auma." (Whitfield, 2011: 177-178)

The closest comparison is to the contemporary western concept of the I/me, and consists of the person's good qualities that distinguish the person from other individuals.

\section{Ama}

The ama is a simulacrum (an immaterial double of the living person with magical powers) of the auma, which remained with the family until 
the obsequies were completed. An apparition of the ama would appear to relatives after death allowing them to see their loved one for the last time. It assisted the family during the mourning period by detecting those responsible for the death, in avenging the deceased's death and by enhancing food presentations. A dying person would tell their loved ones that his ama would assist them after his death, as he realized that the funeral was a great burden on the family, and believing that he could help after death eased the pain of separation. The ama gave endowments of yesegi and aona to family members, or other mourners who consumed the body of the deceased out of love. After the departure of the ama to kwelanamandi it could still be called upon to assist the living through the relics of the deceased.

Certain bones had a strong connection with the ama, especially the collar bones and jawbone, and the hair of the deceased. The relics acted as talismans by providing a portal to the deceased's ama, which assisted the family members with their requests. These requests might include help in battle, protection from sorcerers, a cure for an illness or to find a lost pig. Gradually, the link between the living and the deceased faded as the next generation passed away, and the ama no longer assisted the living. The ancestor had forgotten the living, and their hair and bones were then left by their sepulture.

\section{Kwela}

The kwela was the dangerous soul of the deceased which could harm the deceased's family members. The kwela formed from the matrilineal flesh and blood, and as the body decomposed it became more and more powerful. The smell of decomposition was the kwela that travelled on the wind, as a cloud of pollution in the form of a human, and harmed the women and children of the family of the deceased if the obsequies were not performed correctly.

As the body decomposed the kwela became immensely dangerous; so exposed sepultures, which were baskets or platforms built in sugar cane or bamboo groves, were built far away from human habitation to ensure that people did not come into contact with the kwela. If the body was buried most of the pollution from the decomposition remained in the burial pit, so the kwela was not as dangerous. Finally, if the body was consumed the kwela remained in the female affines, called anagra in South Fore, for an equivalent period of time to decomposition on an exposed sepulture, thus rendering the kwela even less dangerous. The kwela of the deceased would not harm those of the same matrilineal blood, so the affines could safely consume the body.

Although we have used the term soul to describe the kwela, it is important to understand that the kwela undergoes a transformation during the liminal period from a dangerous soul, with ghost-like behaviours, to a benign soul, as the matrilineal blood and flesh are removed during decomposition. Finally, the kwela is purified when it crosses the red river at the entrance to kwelanamandi. The benign kwela that makes up part of an ancestor at the end of the mortuary rites is the part that arose from the patrilineal blood of the deceased, purified of matrilineal substance.

\section{Yesegi}

Yesegi was the term used to describe a man's aggression, way of thinking, lack of fear and the supernatural power of his aona. It was a man's yesegi that made him a great warrior or a powerful sorcerer. Yesegi was the power of a person's aona and the two were intimately linked. It came from three possible sources: firstly it was received from the amani with aona during initiation rites; secondly it could be inherited from a deceased family member; and thirdly it could come as a powerful endowment from the ama. Yesegi was part of a person's skin when he was alive and it departed from the body with the kwela after death. The yesegi of the deceased was normally transferred to one of the deceased's sons, and this gradually became apparent as he grew older. Women who helped carry shields or wielded clubs during battles also had yesegi. Not everybody had yesegi, but it was evident in those who possessed it.

\section{Aona}

Aona can be described as a person's abilities, and came from three possible sources: as an endowment from the ama of a deceased person, inherited from a person's deceased parents, or from the bagina via the amani during initiation rituals. People's aona might make them good gardeners, hunters, raisers of pigs, distributors of food, warriors, bilum makers etc. People were not born with aona; it was something they gained during their lives. When people became old their aona dissipated, and they would say that it was time for them to die as their aona was weak. The ama transferred the deceased's aona to his favourite child, who was normally the oldest child of the same sex. As well as the aona of the deceased, a child or other relative might receive aona from the ama in the form of an endowment during mortuary rites. 
The opportunity for initiates to acquire aona and yesegi from the amani happened at the following initiation rites: kokana, andamana and akitona. It also occurred on the night before a man was married. During akitona initiates had a vision of an animal or plant, which became their familiar spirit - the connection between a man and the bagina. A man's character was also affected by his familiar spirit, so if the familiar spirit was an aggressive animal, then the initiate would be aggressive, as he had also received yesegi. Men never ate their familiar spirit, as it would destroy their aona.

Once a man had a familiar spirit (aona) he received visions from the bagina when under the influence of a hallucinogenic drug mix made from the bark of the agora tree and ileleva (wild taro). The drugs released the ama from the body, so it entered the world of dreams and visions, and the user's aona connected with the bagina to receive its assistance. The familiar spirit would appear in dreams or visions and assist a man by warning him of dangers, or tell him where to find pigs or possums when hunting (these are just some examples).

Contact with a decomposing body through touch, smell and ingestion would contaminate a warrior or an initiate, and damage his aona. The men avoided those who ate the dead, so that their aona was not damaged. Food taboos were designed to protect a man's aona, as were many of the rules of the men's cult houses. There were also rules to protect a young woman, in particular those who were newly married, from the pollution of a corpse. Although this rule was to protect the woman, in reality its principal purpose was to stop her from becoming a danger to her husband's aona.

Ivaena was the first ritual where women might gain aona from their patrilineal amani or the ama of an ancestor. This was performed the night before a woman was sent to live with her husband's family (Whitfield, 2011:177-190).

\section{Transumption in the South Fore}

The term 'transumption' for these mortuary practices was first used by Alpers in 1999. It is defined as:

« the mortuary practice of consumption of the dead and incorporation of the body of the dead person into the bodies of living relatives, thus helping to free the spirit of the dead. " (Alpers, 2007)

This practice had deep religious significance for the people of the kuru-affected region and surrounding groups. It was therefore not appropriate to use the term 'cannibalism' or even 'endocannibalism' for these practices, to which contemporary members of these societies give such good witness, because of the strong negative and derogatory connotations of these terms (Fisher, 2010: 91).

\section{The journey of the auma to kwelanamandi}

When a man was dying his familiar spirit would come and grieve over him and then die. The family would find a dead snake, lizard or whatever was the dying man's familiar spirit near their village, and they then knew that the man was about to die. The familiar spirit was the connection between the bagina and the initiated man, and this connection was broken just prior to death.

His favourite maternal uncle would open the door to kwelanamandi by exonerating the deceased for any offences he had caused the affines during his life. As death approached a man would tell his relatives that the ancestors had come to accompany him on his journey to the land of the ancestors. To reach kwelanamandi the deceased had to look aggressive, so he could frighten away the wild ghosts, kavugi, and open the road to kwelanamandi. The kavugi inhabited the amani and were omens of death and protectors of the road to kwelanamandi. The deceased's auma was escorted by his ama and kwela, and the ama and kwela of the ancestors, to ensure that it arrived safely.

The deceased man's clothing was hung up inside the clan's amani ground, as an offering, and the amani asked to assist the auma on its journey to kwelanamandi. A senior man from the family performed this ritual called autavana.

During the night after the death an agemate would shoot one of the dead man's arrows towards the clan's amani with the deceased's bow shouting out the name of the clan's amani. This informed the amani of the death, and requested its help to avenge the death. Firstly, the deceased's hair was wrapped around the arrow and the arrow was placed in the corpse's hand. When lit the arrow was guided by the ama of the deceased to the amani.

Then the ama was asked to assist finding those responsible for a sorcery-related death, in a ritual called bakana. This soul possession involved the ama of the deceased entering the body of a male family member. The man ate hallucinogenics, performed certain rituals, and as he hyperventilated on tobacco he became possessed by the ama and was able to see the kwela. Once possessed he would explain the cause of death to the other family members. The possessed man followed the kwela, and it showed where the man had died, what had been used to kill him, and who was responsible. 
After death the auma walked across the bagina and said farewell to it. When it reached the amani, the amani asked why he had died, and after feeding the auma, the amani showed it the road to kwelanamandi. The shadows of whatever was put on the body would go to kwelanamandi with the auma. The shadows of the funeral items were simulacrums of mortuary items that could be used by the deceased in kwelanamandi. After 2-3 days the auma and the escorting ancestors crossed the red river at the entrance to kwelanamandi, and after being welcomed by the ancestors settled on its allocated ground. The deceased's ama and kwela turned back at the red river, and returned to be with the body.

\section{Sites chosen for the disposal of the body}

Once the body started to decompose the relatives knew that the auma had entered kwelanamandi and it was time to dispose of the body before the kwela became too dangerous. Traditionally transumption was the most common method of disposal of a corpse in the South Fore, and many of the bodies that were placed in graves, baskets or on raised platforms were later removed and eaten out of love and respect for the deceased. Sepultures were normally next to a bamboo, sugar cane or casuarina grove, as they provided shade and marked the sepulture. They also needed to be far enough from the village to avoid polluting it. There were a few cases when the body was not consumed, such as when the person died of a 'natural disease' such as epidemic dysentery, or where the agency responsible for the disease, such as leprosy, was thought to be contagious. A few people requested burial as they wished to be eaten by the land, and an even smaller number wished for their bodies to be placed in a basket or on a bamboo platform in their favourite place. However, these bodies were normally removed and consumed by the women who did not want the body to be subject to the process of decomposition.

\section{Participation in transumption}

Ideally, corpses were meant to be eaten by older women who were no longer able to bear children, as their aona was fading. Women with two or more children could participate but were only meant to eat muscle. However, these rules were not enforced and nearly all the females from the age of 3 upwards took part in transumption. There were some prohibitions on newlyweds, but these were removed after the birth of the first child.

Boys participated in transumption with their mothers from the age of 3 until they moved to the men's cult house and became initiates between 6 and 8 years old. Besides the ilevino ritual, initiates and warriors did not participate in transumption. There were a few old men who took part with the women, but this behaviour was frowned upon by the other men.

Ilevino was the name of a secret male ritual that involved eating a small piece of the cooked vagina of a dead female relative by an initiate under the supervision of a male warrior. Only a few chosen initiates took part in this ritual in the hope of receiving aona and yesegi that would make them a powerful warrior. Some male warriors with powerful aona and yesegi from the ilevino ritual continued to perform this secret rite throughout their lives.

A woman's sexual organs were regarded as a shameful source of pollution, in the form of menstrual blood, which endangered the whole community. For this reason both adult men and women colluded in trying to hide the truth about sex and sexual reproduction from the unmarried youth and children. Open discussion about birth, menstruation and sex were forbidden subjects, and men never witnessed childbirth or menstruation. It was the duty of an anagra (female affine) to eat the vagina, and the ama might bestow an endowment on her; however, when a man ate a piece of vagina the ama would hopefully endow him to be a great warrior. This was the most powerful endowment a man could receive. When the woman's ama saw the man's humility and courage when he ate, it would endow him to become a great warrior.

\section{Rules for claiming and distributing a male body}

The body of a male belonged to his matrilineal affines, and normally the senior uncle on the matrilineal side claimed the corpse and oversaw its care, transport to the sepulture and disposal. Sometimes the duty fell to another matrilineal uncle that the deceased was particularly close to. If the body was to be disposed of by transumption he would transfer the duties of division, dismemberment and cooking to the senior female anagra, who was normally his wife. He would stay and witness the transumption of the corpse to ensure that the anagra carried out their duties diligently, and to see if there was any behaviour amongst the guests which might indicate their families' involvement in a sorcery-related death.

In the case of a married man there were at least two groups of anagra: one from his deceased's mother's family and another from the man's wife's family. Ideally, both families came from the same clan, but in reality they were often from different clans.

The oldest son's wife of the deceased man would make a request for part of the body on behalf of the family. This request was not a right, and was made on behalf of the daughters-in-law and other women in the family, who were called 
anatu. Normally, the anatu were given the head and the right arm of the deceased. The arm was symbolic for food, support and protection, and was consumed by the anatu out of respect for the deceased person's good actions to their family. The head was requested as it was symbolic of the deceased's individual humanity: the face was the visual aspect of this individuality.

\section{Rules for claiming and distributing a female body}

If a married woman died her body was claimed by her eldest brother, but this right was transferred to his male cousins who would transfer the right to their wives for the purpose of transumption. Those who had rights in the body of the deceased had also received her bride price. In the distribution of the body the anagra and the anaso (an older woman from the same clan as the deceased, who had married into the deceased's husband's clan, and acted as her godmother) had the rights; the senior anatu would request the deceased's arm, head or both, and the anagra normally agreed. The deceased woman's daughters who had married out would attend the obsequies with their families and participate in transumption with the anatu.

The rights to an unmarried girl belonged to her oldest brother but these rights were transferred to his male cousins who would have received her bride price if she had lived, and they transferred it to their wives if the body was to be disposed of by transumption. This was compensation for not receiving the bride price that would have been received if she had grown old enough to marry, and the corpse was consumed by their wives. The female cousins always claimed the head as that was regarded as the most important part of the body by the family.

All the women who had rights to part of the body would receive an equal share. The women held the part that they claimed, marked it with red earth or tied vines around it. Once the body was claimed, and those claims had been mediated by the senior anagra in charge of the obsequy, dismemberment began.

\section{The dismemberment and preparation of a male and female body for transumption}

On arrival at the designated sepulture the body was placed on a bed of wild green vegetables on 2 bark cloths resting on banana leaves. The bed was designed so that none of the body was lost during transumption. The anagra surrounded the top of the body and the female members of the family, if they remained to witness the dismemberment, sat down about a metre away around the lower half of the body. When the body was about to be dismembered the women chased the young children away and told them that if they did not leave the kwela would eat them.

The body was not normally dismembered with close family members present, as it was unbearable for them to watch, so the agnates normally moved away when the anagra dismembered the body. An appointed male family member witnessed the transumption, remembered how the body was distributed and ensured that the body was treated properly. The family recorded the first division of the body then other senior women who received parts of the body recorded each subsequent division, so all the women who took part in eating the body would receive correct purification and compensation payments during aindu, aluana and igoghana.

The senior anagra in charge would start dismemberment of the body with her bamboo knife. It was believed that when the first drop of blood from the body touched the bagina it welcomed the kwela and ama and comforted them.

The body was dismembered by the old anagra: that is, women with grey hair who could no longer bear children. The aona of the older women were already fading, so they were not affected by the pollution of the body. The younger anagra who had rights to part of the body would ask the older ones to cut their parts for them. The younger women were not allowed to cut the body as they would be polluted by the blood and this would pose a danger to their husbands' aona. These men were the warriors who protected the community, and if the pollution reached them through their wives their aona would be damaged, and they would not be able to carry out their defence successfully. Women over the age of sixteen assisted by holding the body during de-limbing. They did not assist for the torso of a man or woman as they were forbidden to see a man's intestines full of excrement and the genitals of either sex, and this part of the obsequy was hidden from all except the elderly anagra. There were two groups of anagra for a married man, one on each side of the body. When a woman died the women of her patrilineal line dismembered the body. Firstly, they cut off the feet and then filleted the legs. The hands were cut off at the wrist, the arms filleted and the bones removed. The leg bones were cut off and the body sat down on the tapa cloth with the back of the torso downwards. The chest and abdomen were cut open and the intestines removed and given to the widow, who hid them in a bilum full of greens. In the pamusagina the widow received nothing, as they believed that if she ate part of her husband his kwela would remain with her forever. In the atigina the widow had to eat part of the body to help her forget her dead husband, and the internal organs were shared amongst the anagra. A woman's body was consumed by her patrilineal line and the older women claimed her 


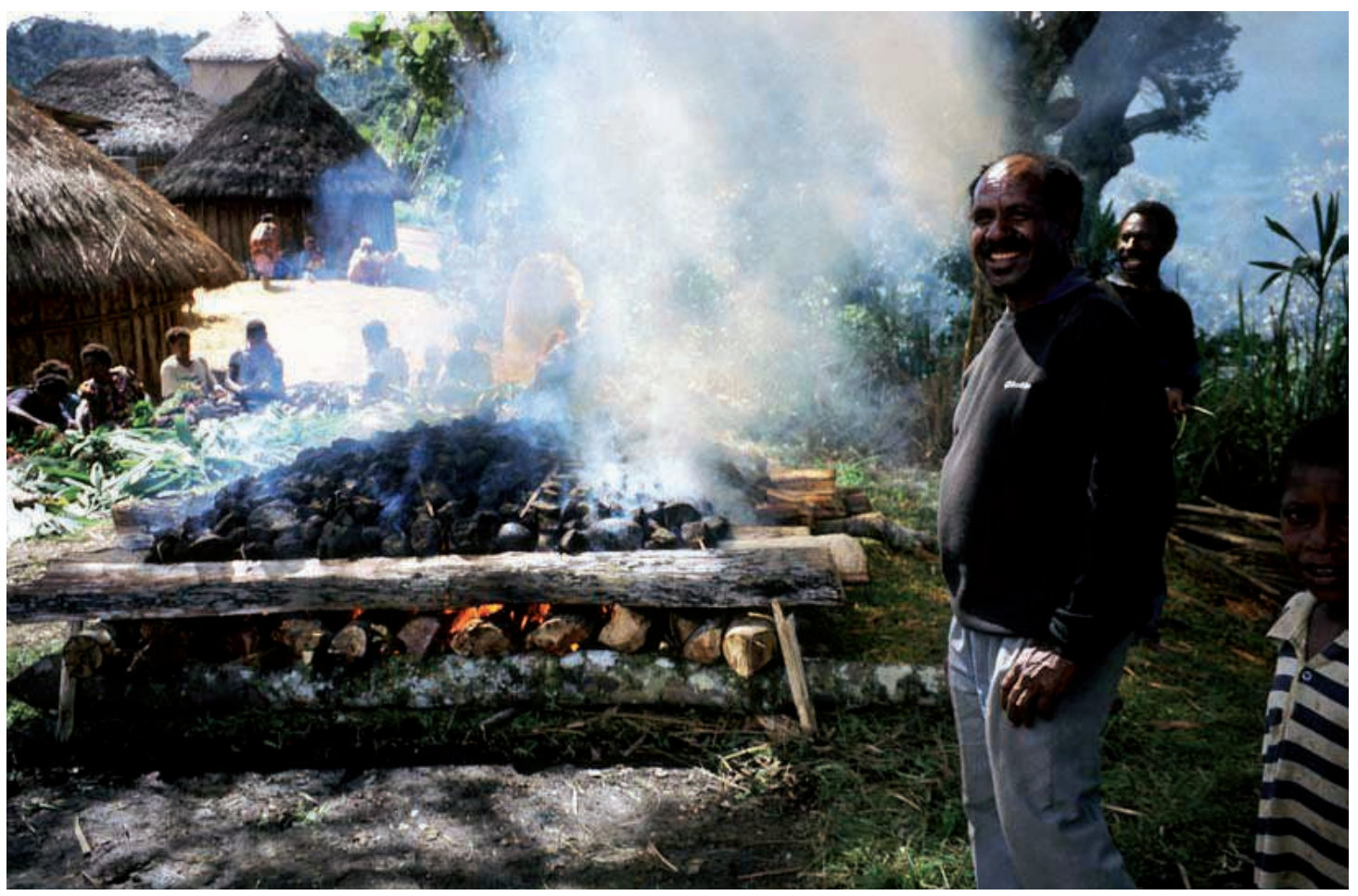

Picture 1. - Mr Anderson Puwa, community liaison officer for the Papua New Guinea Institute of Medical Research and MRC Prion Unit kuru project, and community leader of Waisa village in the South Fore, overseeing a funeral feast in honour of his deceased uncle, Mr Papane Agaya, in 2006 (picture by J. Whitfield)

internal organs and genitals. The older anagra cut the body so that the intestines and genitals remained hidden from the other mourners, and to ensure that this happened they crouched down and made a wall around the body with their bark capes so that the other participants could not see what was happening. The head was then cut off and finally the backbone divided up. As the body was dismembered the person who claimed a particular part took it and put it on a banana leaf plate with a breadfruit leaf on top containing wild ferns. The bones were divided up and placed on top of each pile of meat belonging to the recipients. The daughtersin-law of the anagra, or their own daughters, would assist them in subdividing the meat, so it could be shoved inside the bamboo tubes with wild green vegetables, and once cooked shared with the ename (unrelated female guests who lived in the same or neighbouring villages). Wild green vegetables symbolized that the deceased had departed to another world - to a wild place where he would forget the living.

The intestinal contents were emptied into a hole under the fire where the body was to be cooked, while hidden by the capes of the anagra. The gall bladder was also buried under the same fire. The intestines were washed out, cut up, dried on the fire to make them softer, and then stuffed into bamboo tubes with wild green vegetables and spices. Certain women mixed spices in their mouths and then spat them on the meat so that it tasted better. Ginger, traditional salt, and other herbs and spices were used. The body was always cooked in bamboo tubes as it was imperative that the whole body was eaten and if a traditional earth steam oven (picture 1) was used fluids from the body would have seeped into the ground.

\section{Transumption: subdivision and consumption of the corpse}

The bamboo tubes were placed on the fire, and turned frequently by the women, so the meat cooked evenly over a period of about 20 minutes. Breadfruit and banana leaves were heated on the fire to make them soft by the anagra and their assistants, and then a large plate of banana leaves was made on the ground. Breadfruit leaves were prepared to act as separate plates for the distribution of the cooked meat. Each anagra and the anaso would empty half of her tubes' contents onto the communal leaf plate, the contents of which were given to the other female guests who came to mourn the deceased. The anatu did the same, and half of the tubes that contained the brain were contributed to the communal pile.

The body was shared with the female visitors from surrounding villages (ename) who had a connection with the deceased. Piles of food were prepared for women from particular villages or 
clans and the senior woman from each group controlled the distribution. All the female participants received part of the body as they had come out of sorrow, and the family and affines had to ensure that they were treated well. The intestines, spine, internal organs and genitals were not shared with the ename. When women attended the obsequies, they showed that they and their families were not involved in the death since, if they did not eat, their husbands would have been suspected of being involved in a sorcery-related death. If a woman's husband had been involved in the death the deceased's kwela would attack her. This attack often took the form of stomach ache, which was interpreted as the kwela attacking the woman in revenge. Some women relished the opportunity to eat the cooked meat, and had a reputation for this in their communities.

The ename were fed from the end of a sharpened piece of bamboo, and the women from the same lineage as the deceased received their meat on a banana or breadfruit leaf and ate with their hands. This protected the ename's families from the kwela. If the meat touched the woman's skin the kwela might remain on her skin, and then harm her family if a member had upset the deceased when he was living. The kwela would not harm the women from the family who ate the body as they ate out of love, so they could eat with their fingers from a banana or breadfruit leaf. This ritual showed the ideal group loyalties: those from the same community were trusted and ate with their hands and those from other communities ate from a stick. However, it was also a way of protecting the ename, who were welcome at the feast, from harm.

The anagra and anaso shared their meat with their daughters-in-law and their children, their 'poromeri' (Tok Pisin for agemates) who supported them at this time, their daughters and their children, and their mothers if they were still alive.

If the anatu received an arm, a finger would be given to each of the children of the deceased to eat if they were still small. The fingers were cooked in bamboo with greens and the flesh eaten, and then the bones crushed, cooked with greens in bamboo and eaten. A woman or child might receive an endowment (aona) by eating a parent's or grandparent's finger; in this situation the endowment was given by the ama out of respect for the person's sorrow.

In the pamusagina the mother-in-law would eat the dead man's penis and the senior mother's brother's wife would eat the testicles; it was believed that if the younger women ate them they would become ill. The older women might receive an endowment from the ama of the deceased by eating the sexual organs. The brain, sexual organs, spine and internal organs were meant to be eaten by elderly females, but in practice the rules were not enforced. Newly married women from the agnates and affines who took part in transumption received part of the body on a stick, so they did not pollute their husbands.

The mourners ate at the sepulture and when evening approached took their remaining bamboo tubes back to the house of one of the anatu in the women's area of the hamlet (kami). The tapa cloth used to carry the corpse was put on the ground and breadfruit leaves placed on top before the meat was emptied from the remaining bamboo tubes. The anagra shared the meat on the tapa cloth with the close female relatives who stayed in the mourning house that night.

The head was not always eaten with the body, as the family tried to keep it for as long as possible, so they could continue to look at the deceased person's face. Once the face changed, that is, when it started to decompose, it was eaten as this signaled that the auma had reached kwelanamandi, and from then on only memories would remain. In the morning, the head of a man was taken to the boundary between the kami and the men's area, and shown to any of the men who wished to see the deceased person's face for the last time.

The head was then placed on wild green vegetables on a large concave stone to retain any fluids. Firstly, the hair was pulled out, and this required little effort. A cut was then made with a bamboo knife from the forehead to the back of the head and the skin peeled off. Next, the jaw and tongue were removed, and then the rest of the skin and meat. A large hole was made in the top of the skull using another stone from a river, and fingers wrapped in greens were pushed into the hole and the brain loosened from the skull. The brain hemispheres, cerebellum and brain stem were then pulled out through the hole. The skull and the broken parts from the cranium were browned by the fire. The brain was mixed with wild green vegetables and put in bamboo tubes. The meat from the skull was shared amongst the anatu and the other women of the deceased's family. The hair that was not kept to contact the deceased's ama was burnt and the ashes mixed with greens and cooked in bamboo tubes and eaten. Fluid left in the tubes when the contents were removed was drunk and grease on the hands wiped on the participant's hair and skin. The brain tissue and meat were cooked separately. Finally, the two stones used to process the skull were taken to the sepulture and placed next to it.

Pregnant women rubbed fluids from the cooked body on to their abdomens, and later checked their newborn children for signs that indicated that their babies had inherited a physical feature, such as looks or a birth mark, from the deceased. The ama transformed the baby to have the behavioural mannerisms and general appearance 
of the deceased. This was an endowment from the ama of the deceased, and was called andagosa.

\section{Ikwaya ana}

The flesh from the corpse was consumed on the first day and night, and on the following day any remaining flesh was consumed with the bones. The women departed from the widow's house with the bones, any leftover meat, and bamboo knives and containers used during transumption.

The bones were placed by the fire to dry, so they would break into smaller pieces without sharp edges. Then the women crushed them with stones in nase, a wild green vegetable, covered in ikwaya (another wild green vegetable), which had been chewed, so the bone dust stuck to it; the greens were then wrapped up, placed in bamboo tubes, and cooked. They were eating a loved one, and the deceased's ama and kwela witnessed the obsequies, so the body had to be treated with respect.

After cooking the bones the women started to eat them, and as evening approached they returned to the mourning house and remained there till transumption of the body was completed. The process of consuming a body could take up to three weeks.

An appointed family member watched over the eating of the bones during ikwaya ana to ensure that the rituals were carried out correctly. All the leaves, bamboo containers, knives and anything else used during the mortuary rituals were burnt on fires and the ashes mixed with wild green vegetables and eaten. This ensured that the entire body was eaten, and the deceased became an ancestor. The ashes were prepared in the same manner as the bones.

At the end of ikwaya ana the fireplace was covered up with earth and became the temporary sepulture for the ama. The stones used to break the bones were cleaned with banana skins which were then burnt in the fire, and the stones returned to the bamboo grove or sugar cane grove which marked the sepulture.

After the body was eaten the anagra felt as though the deceased was within them, and this reduced the grief of the participants. Even though the person had died, he or she was still with the living, and had not yet departed; the souls only departed when the grief had subsided and people had accepted the death. Transumption reduced the grief of the mourners and shortened the mourning period.

Once the fireplace was covered up the family would light a small fire by the side of the sepulture in the morning and afternoon. Food and water were placed there as the ama was cold, hungry and thirsty. This started after transumption and continued until aindu.

\section{Mortuary rites following the transumption of the deceased}

\section{Isosoana}

This feast was held after the deceased's bones were consumed and included the pepatakina ritual. This feast was for all those who grieved and was held in honour of the deceased. Women from the village who were not in the mourning house collected vegetables and prepared an earth oven inside the hamlet of the deceased.

\section{Pepatakina}

The women left the mourning house in a ritual called pepatakina; this required the use of the leaves from the earth oven used to prepare isosoana, a feast of vegetables, some of which were prepared for the women when they came out of the mourning house. The cooked leaves were placed on the ground from the entrance of the mourning house to the piles of food for the women who had consumed the body. When the women walked on the leaves the steam purified their bodies. The next day the women started to prepare for aindu as pepatakina freed them to move around the kami -- except for the widow, who remained at the back of her house.

\section{Aindu}

Aindu was the name of the second purification ritual after the completion of transumption. This ritual was normally performed three days after isosoana to remove the pollution from those who had taken part in transumption. The ritual freed the participants to carry out normal domestic duties again, such as gardening, and most importantly allowed them to engage in activities to assist the obsequies. The women collected wild and domestic green vegetables and hunted garden rats, and the men hunted tree kangaroos, possums and wild pigs. Everything was taken to the kami where the women gutted the animals and placed them on the fire in the mourning house. The burning fur and fat gave off a strong smell that purified the kami. The women then purified themselves by rubbing the carcasses over their bodies, grass skirts and bark capes. Finally, the women cooked the carcasses in bamboo tubes and ate them. If a bark cape was used to carry human meat it too was purified. Sometimes children took part in aindu, but it was not as important for them to be purified as they did not possess aona. This ritual purified the bodies of the participants of transumption and the village, and ensured that the whole body was consumed. 


\section{Kavunda}

Isosoana marked the start of kavunda, the grieving period. When grass started to appear on the grave it signalled the end of kavunda and the family then started to prepare for aluana. Kavunda meant 'eating of wild greens'. It lasted for one or two months when the mourning was still intense, and friends and relatives continued to visit the grieving family. The anatu collected vegetables from their gardens in the village and continued to feed the guests, and when the garden foods were finished they collected wild ferns, sweet potato leaves and grasses. Every few days a steam oven was prepared full of sweet potatoes to feed the family and guests, and visiting male relatives brought wild meat to bolster the mourners' diet. During the night the mourners sang and expressed their grief.

The stems of the consumed wild plants were heaped in a pile, and at the feast called aluana, which marked the end of kavunda, they were burnt. During forays into the forest to collect wild green vegetables, edible plants that the deceased had seen or touched were collected, cooked and eaten. By eating items connected to the deceased the mourners remembered their loved one and this helped them to overcome their grief.

\section{Aluana}

Aluana was the last feast to remove pollution from the mourners (except the widow) and consisted of wild meat presentations. Sometimes a domestic pig was added to thank the affines for consuming the body. Normally, the feast took place a couple of months after the body was consumed, and marked the end of kavunda and the public mourning of the community.

The men hunted possums, wild pigs, cassowaries and eels, whilst the women and children hunted rats and collected grubs. The food was presented to all the women who had participated in the transumption of the body.

At the end of aluana the kwela departed from the temporary sepultures, which were the bodies of the anagra, and joined the ama at the sepulture, which was the fireplace where the body was cooked. After aluana the women were free of pollution and able to concentrate on preparing gardens and raising pigs for agona and igoghana. It was a tremendous relief for the anagra when the kwela departed from their bodies. However, close family members continued to mourn the loss of their loved one, and the widow remained in mourning and under certain prohibitions until after agona.

\section{Igoghana}

Igoghana often required the rearing of pigs, so it took place two years after transumption when pigs had been specifically raised. Igoghana consisted of presentations of cooked pigs and vegetables given to the families of those who consumed the body, as a payment for the service of eating something that was not meant to be eaten (the body was a source of pollution and not meant to be consumed). The payment was made to the senior males of the families who had participated in transumption, and not to their wives.

\section{Agona}

Preparations for agona took between two and three years, as it required ten to twenty-five pigs depending on the importance of the deceased. This payment was for the matrilineal blood that allowed the patrilineal line to reproduce and continue. The payment was known as head pay' and consisted of: bows, arrows, headdresses, crops, salt, toea shells, stone axes, and cooked and live pigs. These items were not equivalent to the life of a person, but a means of thanking the affines. It is important to recognize that this redress were never equivalent to the loss of a loved one for the family. It was a material apology, and the aggrieved family did not privately forget, or forgive the perpetrators. All the affines received part of the agona payment, and other participants who had various rights received small payments of food.

The kwela and ama were told by the mourners that life was much better in kwelanamandi with their ancestors, and told to depart. Firstly, they said goodbye to the bagina, then ate with the amani and continued on the road to kwelanamandi. The shadows of all the food and items used at the mortuary feasts went with the kwela and ama to kwelanamandi. After agona the family was sad, as the deceased had finally departed forever. Once the kwela and ama arrived in kwelanamandi they were reunited with the auma, and the deceased was reborn as an ancestor. The shadows of all the food and goods used during the mortuary rituals allowed the deceased to prepare a feast for the ancestors.

\section{Conclusion}

The person's connection to the cosmos was made apparent at birth and death. The South Fore understood the conception of the person, composed of patrilineal and matrilineal humors brought together, as the result of social and biological processes. The transumption of the physical body and the departure of the souls followed Hertz's theory of secondary burial (Hertz, 1960). Detailed ethnographic descriptions of South Fore mortuary rites proved fruitful in eliciting an indigenous understanding of personhood. 
However, the ethnographic data also highlighted the conundrum facing Stewart and Strathern (2001) in understanding indigenous concepts of noman amongst the Melpa and their neighbours. To understand the meaning of the 5 souls of the South Fore it was necessary to contextualize them within the cosmos. Single words or phrases were inadequate to describe such entities. Indeed, the kwela changed from a soul with ghost-like behavior to a benign soul by the end of the mortuary rituals. The South Fore gave different descriptions for the auma. The aona could take multiple forms, such as a plant or animal familiar spirit, and was also described as a person's abilities in combination with yesegi.

The humors of the body were divided into the bones, and the flesh and blood. Their soul counterparts were the ama, which represented social ideals of behaviour, including exchange and reciprocity, and the ambiguous kwela. Yesegi was found on a person's skin, and the aona in the body. Only after death was the person reconstituted as a socially ideal person, in the form of pure patrilineal substance, as an ancestor. For this to happen, the kwela, which was initially ghost-like in its behaviour, had to be purified of matrilineal blood and flesh that manifested from the putrid substances of decomposition to become a patrilineal soul formed only of patrilineal blood. Once transformed, the souls of the deceased returned to the amani, from whom they originated, and finally to the bagina, the creator, when they entered kwelanamandi. This cosmology allowed for a number of ways to dispose of the deceased, including platforms, baskets, burial and transumption, all of which achieved the same end results, and precluded the consumption of enemies within the same cosmological context.

The very notion of cosmos as described by Stewart and Strathern (2001:145-146) flowed through the embodied South Fore person. The souls and humors of the person came from the bagina via the amani, and all were returned to the bagina at death. The South Fore cosmology was written into the landscape and both were part of an overarching cosmos that covered the relationships between its inhabitants, and between the inhabitants and their living environment, in this case the bagina and its metaphysical creations. It was from locales in the landscape, which were sites of mythological events, that power emanated and penetrated a person's personal space (Weiner, 1983).

People were hubs of wider relationships and the souls and humors of a deceased person carried influence and power during mortuary exchanges, which came from the truth that was written into the landscape. This power flowed, in mediated and unmediated exchange, in the objects and humors of the deceased. The correct performance of the mortuary rituals was rewarded with endowments and assistance from the $a m a$, and the incorrect was punishable by the kwela. The deceased's aona and yesegi were inherited by their children. Bones and objects, such as bows or arrows, that belonged to the deceased maintained a connection to the ama and acted as talismans. The correct performance of the rituals was the way of the ancestors and expressed the power of truth.

Embodied persons were part of the cosmos and linked in both moral and physical terms through their souls and humors. This meant that a person's social interactions were informed by ideas of cosmology, morality, ancestrality, mythology and power that emanated from the landscape, as part of an overall cosmos. Culturally approved behaviour followed the way of the ancestors, and thus contained their power of speech. This meant that all social acts contained the power of truth if performed within a group's culturally prescribed norms of correct behaviour. A person's auma was evident in their moral behaviour, aona in their abiltites, such as dividing food at a mortuary feast, and yesegi in a warrior's abilities when the community needed defending. When people failed to abide by the way of the ancestors they were punished by the bagina, or the kwela during mortuary rites.

In the South Fore the embodied person was perceived as an individual composed of humors and souls which were imbued with the power of truth, which emanated from their cosmology and landscape, as part of an overarching cosmos. At death the embodied souls separated from the humors and yet remained linked to them for the duration of the mortuary rites and beyond, revealing the partible person and South Fore concepts of personhood.

\section{Acknowledgements}

We acknowledge the help of the Fore communities and the many individuals who have made this study possible. We thank the Director of the MRC Prion Unit, Professor John Collinge, the Director of the Papua New Guinea Institute of Medical Research, Professor Peter Siba, and its former Director Professor John Reeder, for their support. This study was funded by the Medical Research Council of the UK. We would also like to thank Professor Pierre Lemonnier and Professor Shirley Lindenbaum for their comments on an earlier draft of this paper. 


\section{BIBLIOGRAPHY}

Alpers Michael P., 2007. A history of kuru, PNG Med Journal 50, pp. 10-19.

-, 2014. Medical Research in the highlands: being part of the community does make a difference, in C. Spark, S. A Spark \& C. Twomey (eds), Australians in Papua New Guinea 19601975, St Lucia, University of Queensland Press, pp. 11-30.

Biersack Aletta, 1990. Review of: The Gender of the Gift (M. Strathern), Man 25, 3, pp. 559-560.

Bonnemère Pascale (ed.), 2004. Women as Unseen Characters: Male Ritual in Papua New Guinea, Philadelphia, University of Pennsylvania Press.

Bonnemère Pascale, 2014. A relational approach to a Papua New Guinea male ritual cycle, Journal of Royal Anthropological Institute 20, pp. 728-745.

Bulmer Ralph. N. H., 1965. The Kyaka of the Western Highlands, in Lawrence P. \& M. J. Meggitt (eds), Gods Ghosts and Men in Melanesia: Some Religions of Australian New Guinea and the New Hebrides, Melbourne, Oxford University Press, pp. 132-161.

Clifford James, 1992. Person and Myth: Maurice Leenhardt in the Melanesian World, Durham, Duke University Press.

De Coppet Daniel \& André Iteanu, 1995. Introduction, in de Coppet D \& A. Iteanu (eds), Cosmos and Society in Oceania, Oxford, Berg, pp. 1-20.

Du Tort Brian M., 1975. Akuna, a New Guinea Village Community, Rotterdam, A. A. Balkema.

Fisher Michael M. J., 2010. In the Science Zone II: The Fore, Papua New Guinea, and the fight for representation, East Asian Science, Technology and Society International Journal 5, pp. 87-102.

Geertz Clifford, 1973. The Interpretation of Cultures, London, Hutchinson.

Gillison Gillian, 1993. Between Culture and Fantasy. A New Guinea Highlands Mythology, Chicago, University of Chicago Press.

Glasse Robert, 1965. The Huli of the Southern Highlands, in Lawrence P. \& M.J. Meggitt (eds), Gods Ghosts and Men in Melanesia: Some Religions of Australian New Guinea and the New Hebrides, Melbourne, Oxford University Press, pp. 27-49.
GLICK Leonard B., 1963. Foundations of a primitive medical system. The Gimi of the New Guinea highlands, a dissertation in Anthropology. Faculty of the Graduate School of Arts and Sciences of the University of Pennsylvania, Philadelphia.

Herdt Gilbert,1977. The Shaman's calling among the Sambia of New Guinea, Journal de la Société des Océanistes 33, pp. 153-167.

—, 1989. Self And culture: contexts of religious experience in Melanesia, in Herdt G. \& M. Stephen (eds), The Religious Imagination in New Guinea, New Brunswick, Rutgers University Press, pp. 15-40.

Herdt Gilbert \& M. Stephen, 1989. The Religious Imagination in New Guinea, New Brunswick, Rutgers University Press.

Hertz Robert, 1960. Death and the Right Hand, translated by Needham R. \& C. Needham, Aberdeen, Cohen \& West. [First published: 1907. Contribution à une étude sur la représentation collective de la mort, Année Sociologique 10, pp. 48-137; and 1909. La prééminence de la droite: étude sur la polarité religieuse, Revue Philosophique 68, pp. 553-580].

KuChler Susan, 1988. Malangan: objects, sacrifice and the production of memory, Am Ethnol 15, 4, pp. 625-637.

Lindenbaum Shirley, 2008. The concept of the person in Melanesia, Cahiers internationaux de Sociologie 124, pp. 83-101.

Lipset David,1994. Reviewed Work: Between Culture and Fantasy: A New Guinea Highlands Mythology by Gillian Gillison, Journal of the History of Sexuality 5, pp. 163-167.

LiPuma Edward, 1998. Modernity and forms of personhood in Melanesia, in Lambek M. \& A. Strathern (eds), Bodies and Persons: Comparative Perspectives from Africa and Melanesia, Cambridge, Cambridge University Press, pp. 53-79.

Malinowski Bronislaw. K., 2008. Baloma, the Spirits of the Dead in the Trobriand Islands, Marston Gate, Amazon.co.uk. Ltd [First published in 1916].

Mallett Shelley, 2003. Conceiving Cultures: Reproducing People and Places on Nuakata, Papua New Guinea, Michigan, University of Michigan Press.

Mead Simon, Jerome Whitfield, Mark PoulTer, Shah Paresh,James B. Uphill, Tracy Campbell, Huda Al-Dujaily, Holger Hummerich, John. A. Beck, Charles A. Mein, Claudio Verzilli, John Whittaker, Michael 
P. Alpers \& John Collinge. 2009. A novel protective prion protein variant that colocalizes with kuru exposure. New England Journal of Medicine 361, pp. 2056-2065.

Meggitt Mervyn J., 1965. The Mae Enga of the Western Highlands, in Lawrence P. \& M. J. Meggitt (eds), Gods Ghosts and Men in Melanesia: Some Religions of Australian New Guinea and the New Hebrides, Melbourne, Oxford University Press, pp. 105-131.

Meigs Anna. S., 1995. Food, Sex and Pollution. A New Guinea Religion, New Brunswick, Rutgers University Press.

Morphy Howard, 1990. Myth, totemism and the creation of clans, Oceania 60, 4, pp. 312-328.

Moss Rosalind, 1925. The Life after Death in Oceania and the Malay Archipelago, Oxford, Oxford University Press.

Newman Philip. L., 1965. Knowing the Gururum$b a$, New York, Holt, Reinhart, and Winston.

Panoff Michel, 1968. The notion of the double self among the Maenge, Journal of the Polynesian Society 77, 3, pp. 275-295.

Parrinder Geoffery, 1989. Ghosts, in Sullivan L. E. (ed.), Death, Afterlife and the Soul, New York, Macmillan Publishing Company, pp. 240-245.

Rivers William H. R., 1920. The concept of "soul-substance" in New Guinea and Melanesia, Folklore 31, 1, pp. 48-69.

Robbins Joel, 2004. Becoming Sinners: Christianity and Moral Torment in a Papua New Guinea Society, Berkeley, University of California Press.

Salisbury Richard F., 1965. The Siane of the Eastern Highlands, in Lawrence P. \& M. J. Meggitt (eds), Gods Ghosts and Men in Melanesia: Some Religions of Australian New Guinea and the New Hebrides, Melbourne, Oxford University Press, pp. 50-77.

Schieffelin Edward L., 1976. The Sorrow of the Lonely and the Burning of the Dancers, New York, St Martins Press.

Scoтt Graham, 1980. Fore Dictionary, Canberra, Linguistic Circle of Canberra.

Stephen Michele, 1989. Conclusion: Constructing sacred worlds and autonomous imagining in New Guinea, in Herdt G. \& M. Ste- phen (eds), The Religious Imagination in New Guinea, New Brunswick, Rutgers University Press, pp. 211-236.

Stewart Pamela J. \& Andrew Strathern, 2000a. Introduction: Narratives speak, in Stewart P. J. \& A. Strathern (eds), Identity Work: Constructing Pacific Lives, Pittsburgh, University of Pittsburgh Press, pp. 1-26.

—, 2000b. Fragmented selfhood: contradiction, anomaly, and violence in female life histories, in Stewart P. J. \& A. Strathern (eds), Identity Work: Constructing Pacific Lives, Pittsburgh, University of Pittsburgh Press, pp. 44-57.

—, 2001. Conclusions: Mediating opposites, in Stewart P. J. \& A. Strathern (eds), Humors and Substances: Ideas of the Body in New Guinea, Westport, Bergin \& Garvey, pp. 139-148.

Strathern Marilyn, 1990. The Gender of the Gift, Berkeley, University of California Press.

Tilley Christopher, 1994. A Phenomenology of Landscape, Oxford, Berg.

Wagner Roy, 1967. The Curse of Souw: Principles of Daribi Clan Definition and Alliance in New Guinea, Chicago, University of Chicago Press.

WARDLOW Holly, 2006. Wayward Women: Sexuality and Agency in a New Guinea Society, Berkeley, University of California Press.

Watson James. B., 1983. Tairora Culture. Contingency and Pragmatism, Seattle and London, University of Washington Press.

Weiner A. B., 1983. From words to objects to magic: hard words and the boundaries of social interaction, Man (New Series) 18, 4, pp. 690-709.

Whitfield Jerome T., 2011. Mortuary practices, human genetics and other factors relevant to the transmission of kuru amongst the people of the kuru-affected region in Papua New Guinea, PhD Thesis, Institute of Neurology, University College London.

-, 2015. Theoretical menus: serving savage Pacific cannibals, unpublished.

-, Wandagi H. Pako, John Collinge \& Michael P. Alpers, 2008. Mortuary rites of the South Fore and kuru, Philosophical Transactions of the Royal Society B 363, pp. 37213724 . 


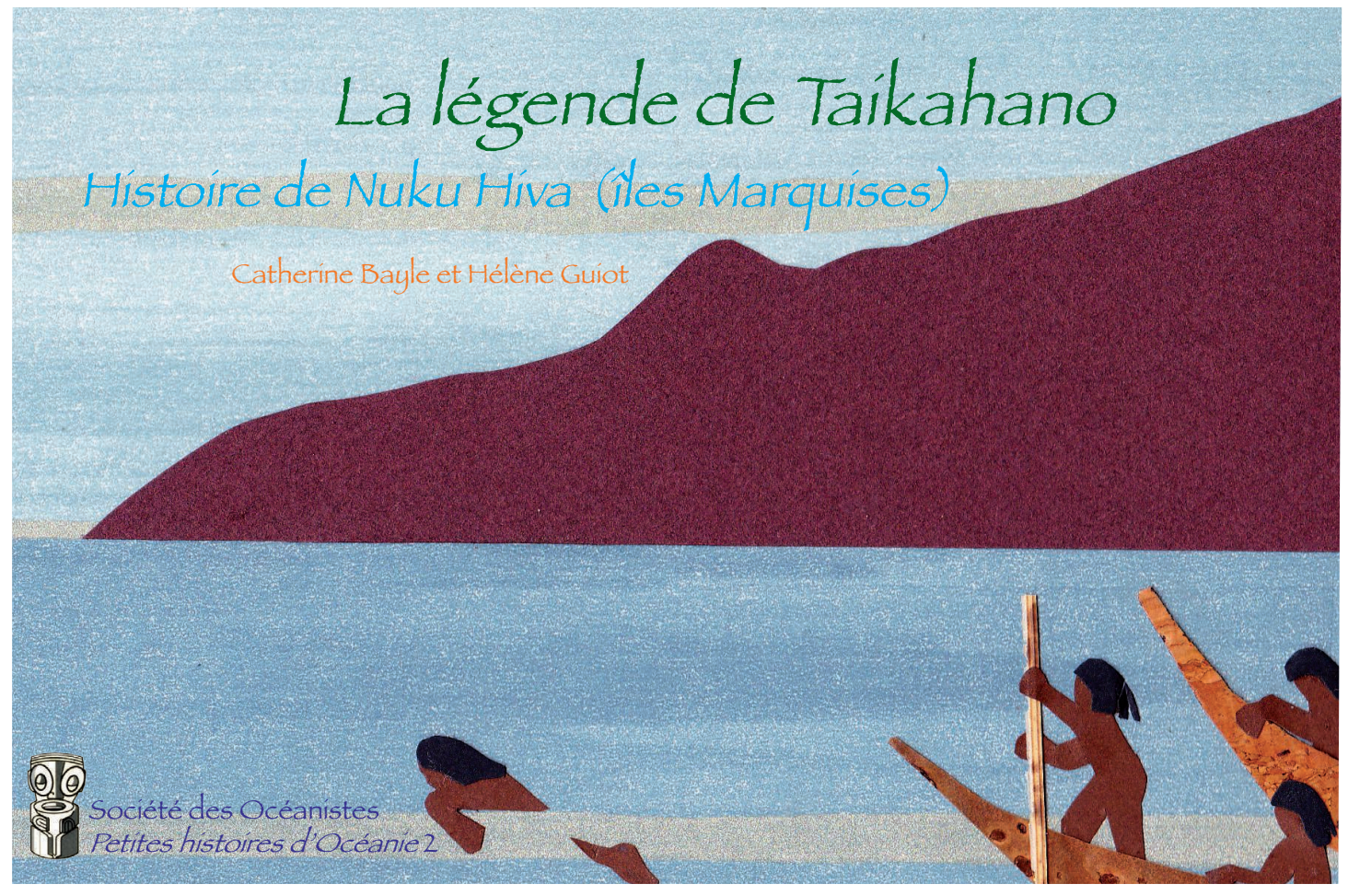

Le volume 2 de la collections Petites histoires d'Océanie sera disponible en mars-avril 2016.

Le volume 1 La jeune fille et le serpent Mââgenin est toujours disponible, soit à la librairie du musée du quai branly,

soit sur http://www.oceanistes.org/oceanie/spip.php?article3833 (paiement en ligne)

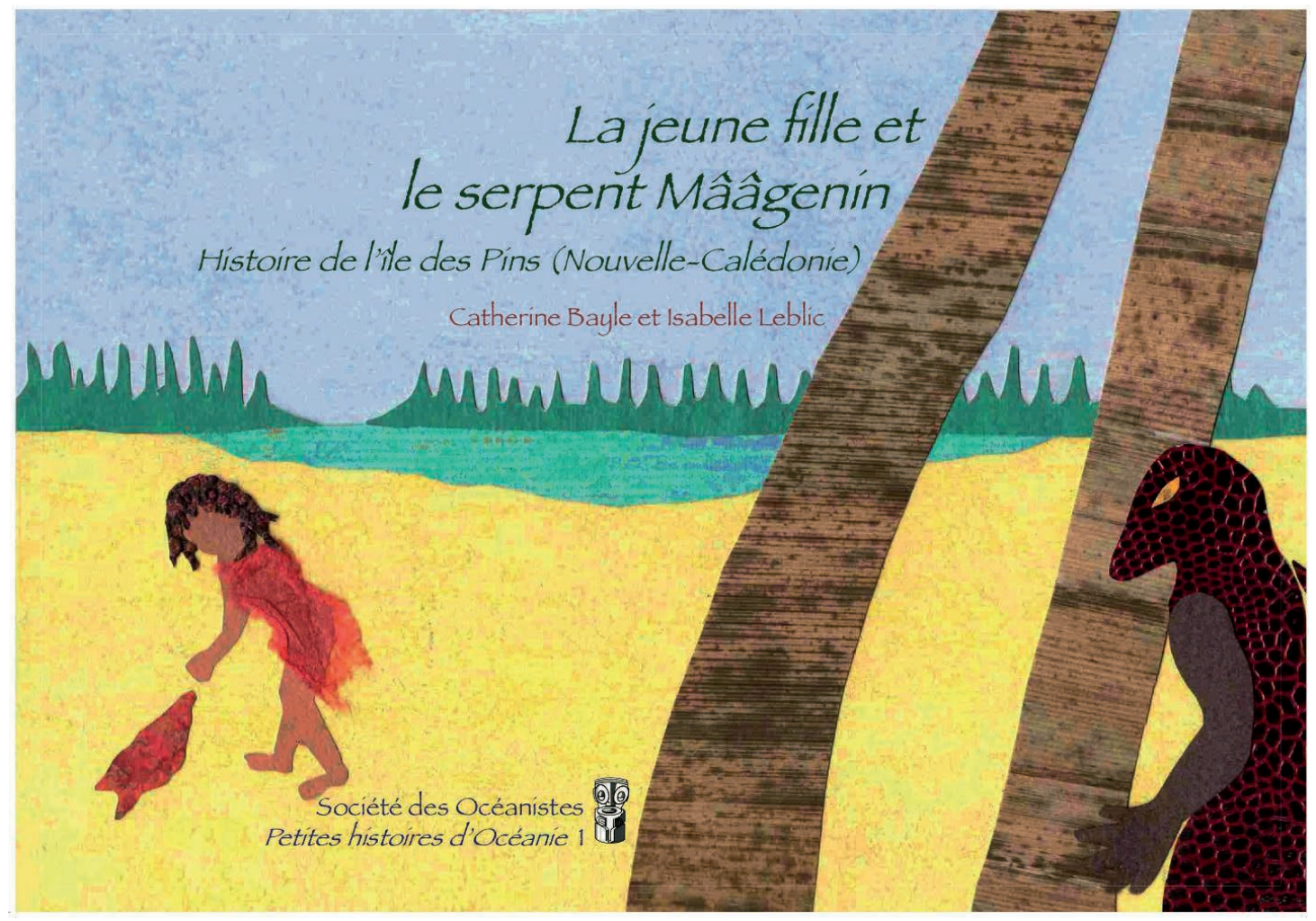

